AGRITECH, Vol. 36, No. 3, Agustus 2016, 270-278

DOI: http://dx.doi.org/10.22146/agritech.16589, ISSN: 0216-0455

Tersedia online di https://jurnal.ugm.ac.id/agritech/

\title{
Pengaruh Perendaman Asam Askorbat dan Natrium Bisulfit pada Dua Varietas Bawang Merah (Allium ascalonicum L.) terhadap Sifat Fisikokimia dan Organoleptik Tepungnya
}

\author{
Effect of Ascorbic Acid Soaking and Sodium Bisulphite on Two Varieties of Shallot (Allium ascalonicum L.) on Physical \\ and Organoleptical Character of Shallot Powder
}

Ermi Sukasih, S. Setyadjit

Balai Besar Penelitian dan Pengembangan Pascapanen Pertanian, Jl. Tentara Pelajar No. 12, Cimanggu, Bogor 16122, Indonesia Email: ermi_sukasih@yahoo.co.uk

Submisi: 9 Juli 2015; Penerimaan: 27 Agustus 2015

\begin{abstract}
ABSTRAK
Kenaikan cukup signifikan pada produksi bawang merah terjadi di Indonesia. Salah satu alternatif pengolahan bawang merah segar adalah melalui pengolahan menjadi tepung sehingga tetap tersedia saat langka dan harganya tinggi. Penelitian ini bertujuan untuk melihat pengaruh perendaman asam askorbat dan natrium bisulfit pada dua varietas bawang merah terhadap sifat fisikokimia dan organoleptik tepung yang dihasilkan. Pengeringan dilakukan dengan tray dryer. Percobaan menggunakan rancangan acak lengkap faktorial, faktor pertama jenis bahan dan lama perendaman dan faktor kedua adalah varietas bawang merah (Bima dan Sembrani). Analisis statistik menggunakan metode Tukey Honestly Significant Data (HSD). Hasil penelitian menunjukkan bahwa perlakuan berpengaruh nyata terhadap parameter kadar air, vitamin $\mathrm{C}$, total fenolik, antosianin, aktivitas antioksidan, inhibisi radikal bebas dan warna (chroma). Berdasarkan uji peringkat diperoleh perlakuan terbaik adalah tepung bawang merah dari varietas Bima dengan perlakuan perendaman asam askorbat 0,2\% selama 30 menit. Karakteristik dari tepung bawang ini memiliki kadar air 4,03 $\pm 0,79 \%$ (bb), kadar abu 4,45 $\pm 0,13 \%$ (bb), lemak 1,24 $\pm 0,64 \%$ (bb) protein 15,56 $\pm 0,28 \%$

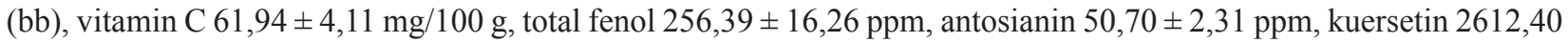
\pm 408,94 ppm, aktivitas antioksidan ekuivalen $225,72 \pm 4,07 \mu \mathrm{g} / \mathrm{mL}$, inhibisi radikal bebas $83,05 \pm 1,69 \%$, nilai ${ }^{\circ} \mathrm{Hue}$ 85,02 (kuning kemerahan) dan skor aroma 3,2 (kuat), skor kecerahan 4,2 (terang) dan skor warna 1,25 (merah pucat).
\end{abstract}

Kata kunci: Asam askorbat; tepung bawang merah; perendaman; natrium bisulfit

\begin{abstract}
ABTRACT
Recently, there is an increase of shallot production in Indonesia. One alternative of flesh shallot processing is shallot powder making which can be used during the off season. The aim of the study was to observe the effect of immersion in ascorbic acid and sodium bisulphite on two varieties of shallot on physical and organoleptic characters of shallot powder. Drying was done using tray dryer. Experimental design used was factorial completely randomised design. The first factor was the type of immersion agent and duration time and the second factor was shallot varieties (Bima and Sembrani). Statistical mean test was using Tukey Honestly Significant (HSD). The result showed that the treatments significantly affected parameters such as moisture content, ascorbic acid, total phenol, anthocyanin, and antioxidant activity, free radical inhibition and color (chroma). From ranking test the best treatment was Bima variety with $0.2 \%$ ascorbic acid treatment for $30 \mathrm{~min}$. Characteristic of the best treatment was with moisture content $4.03 \pm 0.79 \%$ (w/w), ash content $4.45 \pm 0.13 \%(\mathrm{w} / \mathrm{w})$, fat content $1.24 \pm 0.64 \%(\mathrm{w} / \mathrm{w})$, protein content $15.56 \pm 0.28 \%(\mathrm{w} / \mathrm{w}), 61.94 \pm 4.11 \mathrm{mg} / 100 \mathrm{~g}$, total phenolics $256.39 \pm 16.26 \mathrm{ppm}$, anthocyanins $50.70 \pm 2.31 \mathrm{ppm}$, quercetin $2612.40 \pm 408.94$ ppm, antioxidant activity ekuivalent, $225.72 \pm 4.0 \mu \mathrm{g} / \mathrm{mL}$, inhibition free radical $83.05 \pm 1.69 \%, 85.02$ hue value (yellowish red) and aroma score 3.2 (strong), brightness score 4.2 (bright) and color 1.25 (pale red).
\end{abstract}

Keywords: Ascorbic acid; shallot powder; soaking; sodium bisulphite 


\section{PENDAHULUAN}

Indonesia terkenal sebagai negara yang memiliki sumber daya hayati yang melimpah, salah satunya bawang merah. Produksi bawang merah sebanyak 44 juta ton per tahun di dunia. Hal ini membuat bawang merah merupakan kebutuhan hortikultura yang sangat penting kedua setelah tomat (Mogren dkk., 2006). Peningkatan siginifikan terhadap produksi bawang merah terjadi di Indonesia. Angka produktivitas bawang merah meningkat dari 9,54 ton/Ha pada tahun 2011 menjadi 9,69 ton/Ha pada tahun 2012 (BPS, 2012).

Bawang merah memiliki banyak khasiat dalam bidang kesehatan karena mengandung antioksidan terutama dari golongan flavonoid. Kandungan bioaktif bawang merah berdasarkan komposisi kimianya mengandung beberapa jenis gula, asam amino, vitamin, komponen sulfur, enzim, flavonoid, saponin, dan mineral (Soininen dkk., 2012). Aktivitas antioksidan paling tinggi terdapat di bagian luar lapisan bawang merah (Cheng dkk., 2013). Antioksidan dapat menghambat reaksi oksidatif in vivo dan membantu fungsi sistem enzim untuk mekanisme pertahanan diri di dalam sel tubuh (Lu dkk., 2011). Hal ini memberikan nilai tambah nutrisi dan fungsional yang cukup baik bagi bawang merah.

Penelitian sebelumnya menunjukkan bahwa bawang merah dapat mencegah penyakit jantung, desentri, influensa, hipertensi, TBC, bronkitis, asma, dan diabetes karena adanya kandungan nutraceutical yang tinggi. Manfaat bawang merah terhadap kesehatan berupa agen antikarsinogenik, aktivitas antiplatelet, aktivitas antitrombotik, antiasmatik, dan antibiotik. Warna merah pada lapisan kulitnya menunjukkan bahwa bawang merah mengandung antosianin yang merupakan senyawa turunan kuersetin (Mogren dkk., 2006).

Salah satu cara untuk mengatasi peningkatan signifikan produksi bawang merah adalah dengan mengolahnya menjadi tepung supaya dapat menjaga ketersediaan bawang merah saat langka atau harga tinggi. Pengolahan tepung memerlukan teknologi yang tepat agar diperoleh tepung yang bermutu tinggi (terjaga kandungan kimia dan antioksidannya) dan warna mendekati bentuk segarnya. Proses perendaman dan suhu pengeringan merupakan faktor yang penting dalam memproduksi tepung bawang merah. Pada penelitian sebelumnya telah diperoleh data bahwa asam sitrat merupakan bahan yang baik karena mampu menghasilkan tepung bawang merah dengan warna yang baik dan kandungan antioksidan yang tinggi (Setyadjit dkk., 2013). Hal itu mendasari diperlukannya penelitian lebih lanjut dengan menggunakan bahan lain yang mudah didapat, murah, tetapi tetap menghasilkan tepung yang baik. Penelitian ini bertujuan untuk melihat pengaruh perendaman asam askorbat dan natrium bisulfit pada dua varietas bawang merah terhadap sifat fisikokimia dan organoleptik tepung tepung yang dihasilkan.

\section{METODE PENELITIAN}

Penelitian ini dilakukan pada bulan Agustus hingga November 2013 di Laboratorium Kimia Balai Besar Pascapanen Bogor. Bahan yang digunakan adalah bawang merah varietas Bima dan Sembrani, aquades, kalium iodida, iodium, metanol, reagen Folin-Ciocalteau, asam askorbat, amilum, natrium bisulfit, aquabidestilata, $\mathrm{HCl} 1 \mathrm{M}$, asetonitril, $\mathrm{KCl}$, natrium asetat, standar quersetin, indikator BCG (Bromcresol Green), serbuk selenium analisis, $\mathrm{H}_{3} \mathrm{BO}_{3}$, dan larutan $\mathrm{H}_{2} \mathrm{SO}_{4}$. Alat yang digunakan adalah alat-alat gelas, HPLC, kuvet, Chromameter Minolta, tray dryer, oven, buret, timbangan, ultrasonikator, spektrofotometri UV-Vis dan filter millipore $0,45 \mu \mathrm{m}$.

Bawang merah segar sebanyak $15 \mathrm{~kg}$ untuk tiap varietas, dicuci dan diiris dengan alat slicer dengan ketebalan $\pm 3 \mathrm{~mm}$. Bawang merah direndam sesuai perlakuan dan diulang sebanyak tiga kali. Setelah direndam, bawang dibilas dengan air bersih sebanyak dua kali. Bawang ditiriskan di plat seng yang berlubang selama \pm 30 menit. Bawang yang sudah ditiriskan kemudian dimasukkan ke dalam oven tray dryer bersuhu $50{ }^{\circ} \mathrm{C}$ sampai kering (sekitar 15 jam). Bawang merah kering ditimbang lalu diblender dan disaring hingga halus. Tepung bawang merah dikemas kantung aluminium foil dan dianalisis fisiko-kimia dan organoleptik. Percobaan menggunakan rancangan acak lengkap faktorial, faktor pertama jenis bahan dan lama perendaman dan faktor kedua adalah varietas bawang merah (Bima dan Sembrani). Perendaman dengan 5 perlakuan yaitu natrium bisulfit 250 ppm (10 menit), natrium bisulfit 500 ppm (10 menit), asam askorbat $0,1 \%$ (30 menit), asam askorbat 0,2\% (30 menit), kombinasi asam askorbat $0,1 \%$ dan natrium bisulfit 250 ppm (30 menit), dan kontrol (tanpa perlakuan). Analisis statistik menggunakan metode Tukey high significant data (HSD). Analisis yang dilakukan meliputi kadar air dengan metode oven, abu dengan metode oven, lemak dengan soxhlet, protein dengan kjeldahl, dan vitamin $\mathrm{C}$ dengan titrasi (AOAC, 2005), flavonoid meliputi total fenolik (Marinova dkk., 2005), antosianin (Vanini dkk., 2009), dan kuersetin (Phani dkk., 2010), aktivitas antioksidan (Takaya dkk., 2003), dan warna (Hongyan dkk., 2012) serta organoleptik scoring. Uji scoring dilakukan terhadap 20 orang panelis semi terlatih terhadap warna (merah pucat ke merah dengan rentang skor 0-5), kecerahan (gelap ke terang dengan rentang skor 0-5) dan aroma (lemah ke kuat dengan rentang skor 1-5).

Penentuan perlakuan terbaik dilakukan dengan uji peringkat (1 hingga 12) pada setiap parameter pengamatan. 
Nilai peringkat kemudian dijumlahkan dimana perlakuan yang memiliki jumlah nilai peringkat terkecil merupakan perlakuan terbaik.

\section{HASIL DAN PEMBAHASAN}

\section{Analisis Proksimat}

\section{Kadar air}

Tepung bawang merah memiliki kadar air tertinggi pada varietas Sembrani perlakuan asam askorbat $0,1 \%$ yaitu sebesar 7,26 $\pm 0,47 \%$ (bb). Kadar air terendah pada sampel varietas Bima dengan perlakuan kombinasi asam askorbat $0,1 \%$ dan natrium bisulfit $250 \mathrm{ppm}$ sebesar 3,80 $\pm 0,14 \%$ bb. Berdasarkan uji statistika metode Tukey, tepung bawang merah dengan perlakuan perendaman dan varietas memiliki kadar air yang berbeda nyata $(p<0,05)$. Hasil uji beda nyata untuk berbagai parameter pengamatan disajikan pada Tabel 1.

Hasil analisis kadar air tepung bawang merah terendah pada penelitian ini lebih rendah dibandingkan dengan penelitian Rajeswari dkk. (2013) yang memiliki kadar air sebesar 11,6 $\pm 0,03 \%$ (bb). Perbedaan kadar air diduga disebabkan oleh metoda pengeringan yang berbeda. Kadar air yang rendah akan membuat produk lebih awet dan meminimalkan kemungkinan pertumbuhan mikroba. Salah satu kriteria tepung bawang merah terbaik adalah kadar air terendah dengan persentase maksimal sebesar $14 \%$ (Mulia, 2008).

\section{Kadar abu}

Kadar abu tepung bawang merah tertinggi pada bawang merah varietas Sembrani tanpa perendaman sebesar 4,99 \pm $0,07 \%$ (bb). Kadar abu tepung bawang merah terendah pada sampel varietas Sembrani dengan perlakuan natrium bisulfit 500 ppm yaitu sebesar 3,42 $\pm 1,83 \%$ (bb). Berdasarkan uji statistika metode Tukey, tepung bawang merah dengan perlakuan perendaman dan varietas memiliki kadar abu yang tidak berbeda nyata $(p>0,05)$

Hasil analisis kadar abu tepung bawang merah tertinggi pada penelitian ini lebih rendah dibandingkan dengan penelitian lain yang memiliki kadar abu sebesar 8,96 $\pm 0,03$ \% (bb) (Rajeswari, 2013). Hal itu disebabkan oleh perbedaan perlakuan yang menggunakan bahan tambahan berupa tepung terigu, sedangkan pada penelitian ini tidak dilakukan. Kadar abu sebanding dengan kuantitas kandungan mineral total yang terdapat pada tepung tersebut (Farida dkk., 2008). Tepung bawang merah dapat dinyatakan terbaik apabila memiliki kandungan mineral tinggi yang sangat dibutuhkan untuk berbagai proses metabolisme tubuh (Linder, 2010).

Tabel 1. Uji beda nyata dari berbagai parameter analisis tepung bawang merah

\begin{tabular}{|c|c|c|c|c|c|c|c|}
\hline \multirow[t]{2}{*}{ Perlakuan } & \multicolumn{7}{|c|}{ Nilai tengah dan signifikansi } \\
\hline & $\begin{array}{l}\text { Kadar air } \\
(\%)\end{array}$ & $\begin{array}{l}\text { Vitamin C } \\
(\mathrm{mg} / 100 \mathrm{~g})\end{array}$ & $\begin{array}{l}\text { Total fenolik } \\
\text { (ppm) }\end{array}$ & $\begin{array}{l}\text { Antosianin } \\
(\mathrm{ppm})\end{array}$ & $\begin{array}{l}\text { Antioksidan } \\
(\mu \mathrm{g} / \mathrm{ml})\end{array}$ & $\begin{array}{l}\text { Inhibisi radikal } \\
\text { bebas }(\%)\end{array}$ & $\begin{array}{l}\text { Warna/Nilai } \\
\text { chroma }\end{array}$ \\
\hline \multicolumn{8}{|l|}{ Bima } \\
\hline Kontrol & $5,95^{\mathrm{bcd}}$ & $50,26^{\mathrm{abc}}$ & $263,45^{\text {bcde }}$ & $47,69^{b}$ & $223,94^{\mathrm{cd}}$ & $82,48^{\mathrm{cd}}$ & $118,77^{\mathrm{d}}$ \\
\hline Asam askorbat $0,1 \%$ & $5,10^{\mathrm{b}}$ & $63,05^{\mathrm{d}}$ & $283,84^{\text {cde }}$ & $49,54^{\mathrm{bc}}$ & $229,20^{\mathrm{d}}$ & $84,18^{\mathrm{d}}$ & $83,59^{\mathrm{c}}$ \\
\hline Asam askorbat $0,2 \%$ & $4,03^{\mathrm{a}}$ & $61,94^{\mathrm{cd}}$ & $256,39^{\mathrm{bcd}}$ & $50,70^{\mathrm{bc}}$ & $225,72^{\mathrm{cd}}$ & $83,05^{\text {cd }}$ & $85,02^{\mathrm{c}}$ \\
\hline Natrium bisulfit $250 \mathrm{ppm}$ & $5,51^{\mathrm{bc}}$ & $56,39^{\text {cd }}$ & $222,47^{\mathrm{ab}}$ & $54,82^{\mathrm{cd}}$ & $224,05^{\mathrm{cd}}$ & $82,48^{\mathrm{cd}}$ & $83,30^{\mathrm{c}}$ \\
\hline Natrium bisulfit $500 \mathrm{ppm}$ & $6,01^{\text {bcd }}$ & $54,82^{\text {bcd }}$ & $251,09^{\mathrm{abcd}}$ & $50,07^{\mathrm{bc}}$ & $215,70^{\mathrm{cd}}$ & $79,09^{\mathrm{cd}}$ & $83,59^{\mathrm{b}}$ \\
\hline $\begin{array}{l}\text { Asam askorbat } 0,1 \% \text { dan } \\
\text { Natrium bisulfit } 250 \mathrm{ppm}\end{array}$ & $3,79^{\mathrm{a}}$ & $62,17^{\mathrm{cd}}$ & $319,92^{\mathrm{e}}$ & $69,77^{\mathrm{g}}$ & $224,03^{\mathrm{cd}}$ & $83,05^{\mathrm{cd}}$ & $85,02^{\mathrm{ab}}$ \\
\hline \multicolumn{8}{|l|}{ Sembrani } \\
\hline Kontrol & $6,69^{\text {de }}$ & $60,87^{\mathrm{cd}}$ & $282,07^{\text {cde }}$ & $70,12 \mathrm{~d}^{\mathrm{e}}$ & $218,17^{\mathrm{cd}}$ & $80,22^{\text {cd }}$ & $83,30^{\mathrm{a}}$ \\
\hline Asam askorbat $0,1 \%$ & $7,25^{\mathrm{e}}$ & $44,86^{\mathrm{ab}}$ & $198,15^{\mathrm{a}}$ & $46,25^{\mathrm{a}}$ & $165,09^{\mathrm{a}}$ & $61,58^{\mathrm{a}}$ & $83,59^{\mathrm{a}}$ \\
\hline Asam askorbat $0,2 \%$ & $7,26^{\mathrm{e}}$ & $42,43^{\mathrm{a}}$ & $237,96^{\mathrm{abc}}$ & $46,90^{\mathrm{b}}$ & $178,05^{\mathrm{ab}}$ & $66,10^{\mathrm{ab}}$ & $85,02^{\mathrm{ab}}$ \\
\hline Natrium bisulfit $250 \mathrm{ppm}$ & $5,28^{\mathrm{b}}$ & $64,52^{d}$ & $426,98^{\mathrm{f}}$ & $73,58^{\mathrm{g}}$ & $157,23^{\mathrm{a}}$ & $58,75^{\mathrm{a}}$ & $85,02^{\mathrm{a}}$ \\
\hline Natrium bisulfit 500 ppm & $5,38^{\mathrm{b}}$ & $64,99^{\mathrm{d}}$ & $299,92^{\mathrm{de}}$ & $69,63^{\text {ef }}$ & $205,85^{\mathrm{cd}}$ & $76,27^{\mathrm{cd}}$ & $85,02^{\mathrm{a}}$ \\
\hline $\begin{array}{l}\text { Asam askorbat } 0,1 \% \text { dan } \\
\text { Natrium bisulfit } 250 \mathrm{ppm}\end{array}$ & $6,61 f^{\text {cde }}$ & $63,22^{\mathrm{d}}$ & $278,35^{\text {cde }}$ & $79,13^{\mathrm{fg}}$ & $199,59^{\mathrm{bc}}$ & $74,01^{\mathrm{bc}}$ & $85,02^{\mathrm{ab}}$ \\
\hline
\end{tabular}

Keterangan: Angka yang diikuti oleh huruf yang berbeda pada kolom yang sama menunjukkan adanya pengaruh secara tunggal (tanpa interaksi) dari perlakuan tersebut pada taraf $5 \%$ uji Tukey. 


\section{Kadar lemak}

Tepung bawang merah yang memiliki kadar lemak tertinggi adalah varietas Sembrani dengan perlakuan kombinasi asam askorbat $0,1 \%$ dan natrium bisulfit $250 \mathrm{ppm}$ yaitu sebesar 1,77 $\pm 0,23 \%$ (bb). Sementara yang terendah adalah varietas Bima tanpa perlakuan perendaman yaitu sebesar $0,77 \pm 0,18 \%$ (bb). Berdasarkan uji statistika metode Tukey, tepung bawang merah dengan perlakuan perendaman dan varietas memiliki kadar lemak yang tidak berbeda nyata $(p>0,05)$. Kadar lemak tepung bawang merah lebih rendah daripada standar komposisi bawang merah segar pangan Jepang sebesar 1,8 \% (bb). Hal itu disebabkan oleh reaksi dekomposisi lemak selama pemanasan pada pengolahan bawang merah tersebut (STAJ, 2002). Kriteria tepung bawang merah yang baik adalah yang berkadar lemak rendah karena berhubungan dengan daya simpan. Atom karbon yang terdapat pada asam lemak dapat berikatan membentuk ikatan jenuh (tunggal) maupun ikatan tidak jenuh (rangkap). Interaksi lemak dengan oksigen dapat menyebabkan reaksi oksidasi lemak sehingga bahan pangan menjadi tengik (Edwar, 2011).

\section{Kadar protein}

Kadar protein tepung bawang merah tertinggi yaitu sebesar 15,77 $\pm 0,47 \%$ (bb) pada varietas Bima dengan perlakuan natrium bisulfit $500 \mathrm{ppm}$, sedangkan yang terendah yaitu sebesar $12,55 \pm 2,36 \%$ (bb) pada Sembrani dengan perlakuan asam askorbat $0,1 \%$. Berdasarkan uji statistika metode Tukey, tepung bawang merah dengan perlakuan perendaman dan varietas memiliki kadar protein yang tidak berbeda nyata $(p>0,05)$.

Kadar protein pada penelitian ini lebih tinggi dibandingkan dengan penelitian lain yaitu sebesar 10,21 \pm $0,05 \%$ (bb) (Rajeswari dkk., 2013). Berdasarkan standar komposisi pangan Jepang 2002 tepung bawang merah memiliki kandungan nutrien yang tinggi dengan kadar protein sebesar 6,6\% (Science and Technology Agency of Japan, 2002). Hal itu menunjukkan bahwa kadar protein tepung lebih tinggi dibandingkan dengan standar komposisi Jepang tahun 2002. Hal itu karena proses pembuatan tepung menggunakan metode pengeringan yang tepat dengan tray dryer pada suhu $50^{\circ} \mathrm{C}$ sehingga kadar protein tepung bawang merah tetap terjaga meskipun telah mengalami pemanasan (Jayathunge dkk., 2012).

\section{Kadar Vitamin C}

Kadar vitamin $\mathrm{C}$ tertinggi pada tepung bawang merah sebesar 65,00 $\pm 5,30 \mathrm{mg} / 100 \mathrm{~g} \mathrm{(b/b)} \mathrm{pada} \mathrm{varietas} \mathrm{Sembrani}$ dengan perlakuan natrium bisulfit $500 \mathrm{ppm}$. Kadar vitamin $\mathrm{C}$ terendah pada tepung bawang merah sebesar 42,43 $\pm 16,24$ $\mathrm{mg} / 100 \mathrm{~g}$ (bb) pada varietas Sembrani dengan perlakuan asam askorbat 0,2 \%. Berdasarkan uji statistika metode Tukey, tepung bawang merah dengan perlakuan perendaman dan varietas memiliki kadar vitamin $\mathrm{C}$ yang berbeda nyata $(p<0,05)$. Tepung bawang merah memiliki kadar vitamin $\mathrm{C}$ tertinggi sebesar 64,99 $\pm 5,30 \mathrm{mg} / 100 \mathrm{~g}(\mathrm{~b} / \mathrm{b})$ pada Sembrani perlakuan natrium bisulfit $500 \mathrm{ppm}$. Vitamin $\mathrm{C}$ merupakan vitamin yang bersifat hidrofilik dengan peranan penting pada proses metabolik seperti pembentukan jaringan, produksi hormon, antioksidan kuat yang mereduksi stres oksidatif, meregenerasi vitamin E yang memiliki aktivitas antioksidan tinggi (Sancho dkk., 2011). Tepung bawang merah yang memiliki kandungan vitamin $\mathrm{C}$ tertinggi merupakan bukan perlakuan dengan asam askorbat. Hal itu disebabkan oleh reaksi auto oksidasi. Reaksi tersebut menyebabkan konsentrasi asam askorbat berkurang (Rosso dkk., 2007).

\section{Total Fenolik}

Total fenolik tertinggi pada varietas Sembrani dengan perlakuan natrium bisulfit $250 \mathrm{ppm}$ yaitu sebesar 426,98 $\pm 66,11$ ppm, sedangkan terendah pada Sembrani dengan perlakuan asam askorbat 0,1 \% yaitu sebesar 198,16 \pm 20,55 ppm. Berdasarkan uji statistika metode Tukey, tepung bawang merah dengan perlakuan perendaman dan varietas memiliki total fenol yang berbeda nyata $(p<0,05)$. Penelitian ini menggunakan lapisan bagian dalam bawang merah untuk diproses menjadi tepung sehingga ada pengaruh penambahan natrium bisulfit yang mengoptimalkan konsentrasi total fenol. Tepung bawang merah Bima perlakuan asam askorbat memiliki total fenolik lebih rendah daripada natrium bisulfit. Penambahan asam askorbat dapat mengurangi konsentrasi total fenolik karena asam askorbat dapat mereduksi total fenol (Andarwulan dkk., 2012). Komponen fenolik yang dominan terdapat di tepung bawang merah dalam bentuk senyawa intermediet sintesis antosianin berupa asam koumarat dan asam hidroksi sinamat (Ignat dkk., 2011). Komponen fenolik berperan sebagai antioksidan, antikarsinogenik, dan antimutagenik yang baik untuk kesehatan manusia (Sancho dkk., 2011).

\section{Konsentrasi Antosianin}

Tepung bawang merah memiliki konsentrasi antosianin tertinggi pada varietas Sembrani dengan perlakuan kombinasi asam askorbat $0,1 \%$ dan natrium bisulfit $250 \mathrm{ppm}$ yaitu sebesar 79,13 $\pm 11,03$ ppm, sedangkan yang terendah pada varietas Bima tanpa perendaman yaitu sebesar 47,69 \pm 2,15 ppm. Berdasarkan uji statistika metode Tukey, tepung bawang merah dengan perlakuan perendaman dan varietas memiliki kadar antosianin yang berbeda nyata $(p<0,05)$. Bawang merah memiliki antosianin dalam bentuk sianidin 3-glukosida (Rodrigues dkk., 2011). Degradasi antosianin 
dapat terjadi selama proses ekstraksi, pengolahan pangan, dan penyimpanan. Stabilitas dan degradasi antosianin dipengaruhi oleh berbagai faktor misalnya cahaya, $\mathrm{pH}$, suhu, sulfit, asam askorbat,dan lain lain. Stabilitas antosianin dapat ditingkatkan dengan pengikatan o-glikosidik, gugus asil pada molekul gula, ion logam, asosiasi sendiri (Associated-self), kopigmentasi, dan enkapsulasi (Rodrigo dkk., 2011). Penambahan gugus hidroksil, metoksil, gula, dan asam pada gugus gula akan menstabilkan antosianin. Hal itu karena terjadi mekanisme substitusi monoglikosidik menjadi diglikosidik pada antosianin yang meningkatkan kestabilannya (Rosso dkk., 2007). Asam askorbat, gula, asam amino, dan fenolik dapat mempercepat degradasi antosianin karena keempat senyawa ini dapat berkondensasi dengan antosianin menghasilkan phlofaben yang berwarna coklat (Andarwulan dan Fitri, 2012).

Penambahan natrium bisulfit pada pembuatan tepung bawang merah menyebabkan fluktuasi warna. Reaksi reversibel antara $\mathrm{SO}_{2}$ dan antosianin akan membentuk senyawa tidak berwarna tetapi ketika terjadi pemanasan maka antosianin akan kembali ke warna semula. Penambahan natrium bisulfit harus dengan konsentrasi optimum untuk menghasilkan konsentrasi antosianin yang optimum. Bisulfit $\left(\mathrm{HSO}_{3}^{-}\right.$) bereaksi dengan aldehid ( $\left.\mathrm{R}-\mathrm{COH}\right)$ secara reversibel menghasilkan asam hidroksisulfonat ( $\left.\mathrm{R}-\mathrm{CHOH}-\mathrm{SO}_{3}{ }^{-}\right)$. Asam hidroksisulfonat hanya dihasilkan dari keton yang memiliki gugus metil berdekatan dengan gugus karbonil ke 4 dan 7 pada rangkaian cincin karbon antosianin yang akan direaksikan (Davidson dkk., 2005). Reaksi ini terjadi pada tepung bawang merah yang menyebabkan komponen sulfurnya meningkat. Asam hidroksisulfonat sebagai komponen sulfur mungkin dapat menjadi prekursor dalam pembentukan tiosulfinat (Anwar, 2009). Tiosulfinat merupakan salah satu prekursor pigmen lain pada bawang merah (Zang dkk., 2013). Tiosulfinat dapat berinteraksi dengan antosianin dengan reaksi asosiasi sendiri. Interaksi tersebut dapat meningkatkan stabilitas antosianin (Rodrigo dkk., 2011).

\section{Konsentrasi Kuersetin}

Tepung bawang merah memiliki kuersetin tertinggi pada perlakuan asam askorbat $0,1 \%$ sebesar 2612,41 \pm 408,94 ppm varietas Bima sedangkan terendah pada Sembrani perlakuan asam askorbat $0,1 \%$ sebesar $1777,17 \pm$ 233,16 ppm. Berdasarkan uji statistika metode Tukey, tepung bawang merah dengan perlakuan perendaman dan varietas memiliki kadar kuersetin yang tidak berbeda nyata $(p>0,05)$. Tepung bawang merah varietas Bima memiliki konsentrasi kuersetin yang lebih tinggi dibandingkan dengan Sembrani. Senyawa kuersetin pada bawang merah berupa kuersetin 7,4-diglukosida. Kuersetin juga merupakan flavonoid intermediet pada proses biosintesis bawang merah dalam bentuk dihidrokuersetin (Rodrigues dkk., 2011). Stabilitas kuersetin dapat ditingkatkan oleh asam askorbat (Rodrigo dkk., 2011). Kuersetin merupakan salah satu flavonoid yang berdampak baik bagi kesehatan (Nuutila dkk., 2003).

\section{Analisis Aktivitas Antioksidan}

\section{Konsentrasi Aktivitas Antioksidan Ekuivalen (AAE)}

Tepung bawang merah memiliki aktivitas antioksidan ekuivalen (AAE) tertinggi sebesar 229,21 $\pm 1,81 \mu \mathrm{g} / \mathrm{mL}$ pada Bima perlakuan asam askorbat $0,1 \%$, sedangkan terendah sebesar $157,23 \pm 27,97 \mu \mathrm{g} / \mathrm{mL}$ pada Sembrani perlakuan natrium bisulfit $250 \mathrm{ppm}$. Berdasarkan uji statistika metode Tukey, tepung bawang merah dengan perlakuan perendaman dan varietas memiliki aktivitas antioksidan yang berbeda nyata $(p<0,05)$. Analisis aktivitas antioksidan dilakukan dengan metode 2,2-difenil 1-pikril hidrazil (DPPH) untuk menghasilkan data yang baik (Cheng dkk., 2013). Berdasarkan kandungan nutrien bawang merah segar terbesar yang dapat berperan sebagai antioksidan adalah vitamin $\mathrm{C}$ (asam askorbat) sebesar $7 \mathrm{~g} / 100 \mathrm{mg}$ sehingga asam askorbat digunakan sebagai standar antioksidan (STAJ, 2002). Antioksidan dapat menghambat radikal bebas seperti spesies oksigen reaktif yang dapat merusak DNA, RNA, modifikasi protein, dan peroksidasi lipid seluler (Andarwulan dkk., 2010). Hasil penelitian menunjukkan pola peningkatan aktivitas antioksidan dan total fenol hampir mirip pada setiap perlakuan, meskipun berbeda titik tertingginya. Penelitian ini relevan dengan penelitian lainnya yang menyatakan bahwa bawang merah memiliki komponen flavonoid dan sulfur (tiosulfinat) yang berkorelasi positif dengan aktivitas antioksidannya (Lu dkk., 2011). Penelitian lain juga menyatakan bahwa kandungan total fenol dan flavonoid berkorelasi positif dengan aktivitas antioksidan (Chen dkk., 2013).

\section{Persentase Inhibisi Radikal Bebas}

Persentase inhibisi radikal bebas pada tepung bawang merah tertinggi pada varietas Bima perlakuan asam askorbat $0,1 \%$, sebesar $84,18 \pm 0,98 \%$, sedangkan terendah pada varietas Sembrani perlakuan natrium bisulfit $250 \mathrm{ppm}$, sebesar 58,76 $\pm 10,22 \%$. Berdasarkan uji statistika metode Tukey, tepung bawang merah dengan perlakuan perendaman dan varietas memiliki persentase radikal bebas yang berbeda nyata $(p<0,05)$.

Analisis inhibisi radikal bebas ini bertujuan mengetahui persentase penghambatan radikal bebas melalui konsentrasi AAE tepung bawang merah. Hasil penelitian menunjukkan bahwa secara keseluruhan inhibisi radikal bebas cenderung pada kisaran 58 hingga $85 \%$. Kombinasi perlakuan asam askorbat dan natrium bisulfit dapat meningkatkan antioksidan. 
Hal ini karena natrium bisulfit mengandung gugus sulfur oksida yang akan menstabilkan asam dehidroaskorbat yang teroksidasi. Reaksi stabilisasi ini melibatkan pengikatan keton atau aldehid pada asam tersebut. Stabilisasi asam dehidroaskorbat akan meningkatkan konsentrasi AAE (Davidson dkk., 2005). Jika konsentrasi AAE semakin tinggi maka persentase inhibisi radikal bebas semakin tinggi pula.

\section{Warna}

Warna tepung bawang merah ditentukan berdasarkan nilai ${ }^{\circ}$ Hue. Nilai ${ }^{\circ}$ Hue tertinggi pada tepung bawang merah adalah varietas Bima tanpa perlakuan perendaman yaitu sebesar 118,77 $\pm 8,42$ (kuning), sedangkan terendah adalah varietas Sembrani dengan perlakuan natrium bisulfit $250 \mathrm{ppm}$ yaitu sebesar 83,30 \pm 2,69 yang menunjukkan warna kuning kemerahan (Tabel 1). Berdasarkan uji statistika metode Tukey, tepung bawang merah dengan perlakuan perendaman dan varietas memiliki warna yang berbeda nyata $(p<0,05)$. Warna produk pangan yang baik adalah warna yang mendekati warna bahan mentahnya. Penelitian ini menggunakan bawang merah yang berwarna merah dan memproduksi tepung yang berwarna kuning kemerahan. Rentang nilai ${ }^{\circ}$ Hue yang baik adalah 54-90 untuk warna kuning kemerahan sedangkan 90-126 untuk kuning merupakan rentang yang kurang baik. Pengolahan bawang merah segar dengan pengeringan suhu $50{ }^{\circ} \mathrm{C}$ menyebabkan perubahan bahkan kerusakan pada antosianin. Tahapan proses kerusakan tersebut dimulai dengan hidrolisis ikatan glikosidik yang menghasilkan aglikonaglikon yang tidak stabil. Cincin aglikon yang labil terbuka sehingga membentuk gugus-gugus karbinol dan kalkon yang membuat produk berkurang warnanya. Hal ini menyebabkan warna merah bawang merah menjadi kuning kemerahan pada tepung (Zussiva dkk., 2012).

\section{Sifat Organoleptik}

Berdasarkan hasil organoleptik dengan 20 orang panelis semi terlatih diperoleh respon terhadap warna merah, kecerahan dan aroma tepung bawang seperti yang disajikan pada Tabel 2. Respon warna merah tertinggi adalah pada skor 3,25 yaitu tepung bawang merah dari varietas Bima pada perlakuan kombinasi asam askorbat $0,1 \%$ dan natrium bisulfit $250 \mathrm{ppm}$. Warna merah tepung bawang disebabkan oleh kandungan antosianin yang terkandung di dalam tepung. Menurut Dong dkk. (2010), tiosulfonat menjadi prekursor pigmen warna merah muda pada bawang merah. Prekursor pigmen ini dapat berikatan dengan asam amino fenilalanin untuk membentuk antosianin.

Respon terhadap aroma tertinggi adalah 3,8 pada perlakuan asam askorbat $0,2 \%$ dari varietas Sembrani. Aroma bergantung pada senyawa volatil yang menyebabkan bau bawang sangat kuat. Senyawa volatil khas bawang merah berasal dari senyawa propil disulfida dan propil-metil disulfida. Senyawa ini berfungsi sebagai stimulansia atau perangsang aktivitas fungsi organ tubuh sehingga merangsang fungsi kepekaan saraf maupun kerja enzim pencernaan (Jaelani, 2007).

\section{Hasil Penentuan Tepung Terbaik}

Tepung bawang dengan peringkat tertinggi adalah varietas Sembrani perlakuan asam askorbat 0,2 \% sedangkan terendah adalah dari varietas Bima perlakuan asam askorbat $0,2 \%$ (Tabel 3).

Tabel 2. Hasil organoleptik tepung bawang merah

\begin{tabular}{lcccccc}
\hline \multirow{2}{*}{\multicolumn{1}{c}{ Perlakuan }} & \multicolumn{2}{c}{ Warna } & \multicolumn{2}{c}{ Kecerahan } & \multicolumn{2}{c}{ Aroma } \\
\cline { 2 - 7 } Tanpa perlakuan & BM & SR & BM & SR & BM & SR \\
\hline Asam askorbat 0,1 \% & 2,05 & 3,10 & 3,10 & 1,80 & 3,10 & 3,50 \\
Asam askorbat 0,2 \% & 1,25 & 0,85 & 4,20 & 4,20 & 3,20 & 2,65 \\
Natrium bisulfit 250 ppm & 2,00 & 2,20 & 3,25 & 3,00 & 3,35 & 3,80 \\
Natrium bisulfit 500 ppm & 1,20 & 2,25 & 4,25 & 2,55 & 2,45 & 3,70 \\
Asam askorbat 0,1 \% dan natrium & 0.80 & 2,65 & 3,55 & 2,50 & 3,30 & 3,00 \\
bisulfit 500 ppm & 3,25 & 3,20 & 1,95 & 2,10 & 3,65 & 3,35 \\
\hline
\end{tabular}

BM: Bima, SR: Sembrani

Rentang skor: 0-5: Warna: merah pucat - merah

$0-5$ : Kecerahan : gelap - terang

0-5: Aroma bawang: lemah - kuat 
Tabel 3. Hasil penentuan tepung bawang merah terbaik berdasarkan uji peringkat

\begin{tabular}{lcc}
\hline \multirow{2}{*}{ Perlakuan } & \multicolumn{2}{c}{ Rangking tepung terbaik } \\
\cline { 2 - 3 } & Bima & Sembrani \\
\hline Tanpa perlakuan & 4 & 6 \\
Asam askorbat $0,1 \%$ & 2 & 11 \\
Asam askorbat $0,2 \%$ & 1 & 12 \\
Natrium bisulfit $250 \mathrm{ppm}$ & 9 & 7 \\
Natrium bisulfit $500 \mathrm{ppm}$ & 8 & 5 \\
Asam askorbat $0,1 \% \mathrm{dan}$ & 3 & 10 \\
natrium bisulfit $500 \mathrm{ppm}$ & &
\end{tabular}

Tepung perlakuan asam askorbat 0,2 \% memiliki kadar air 4,03 $\pm 0,79 \%$ (b/b). Kadar air kritis tepung bawang merah adalah $14 \%$ (bb) (Mulia, 2008). Kadar abu sebesar 4,45 $\pm 0,13$ $\%$ (b/b), kadar lemak sebesar 1,24 $\pm 0,64 \%$ (b/b). Berdasarkan (STAJ, 2002), tepung bawang merah memiliki kandungan nutrien yang tinggi dengan kadar lemak 1,8\%, karbohidrat 23,5\%, dan kalsium 1,2\% b/b. Kadar protein tepung bawang adalah 15,56 $\pm 0,28 \%$ (b/b), vitamin C sebesar 61,94 $\pm 4,11$ $\mathrm{mg} / 100 \mathrm{~g}(\mathrm{~b} / \mathrm{b})$. Aktivitas antioksidan ekuivalennya sebesar $225,72 \pm 4,07 \mu \mathrm{g} / \mathrm{mL}$. Persentase inhibisi radikal bebasnya sebesar 83,05 $\pm 1,69 \%$, total fenolik sebesar 256,39 $\pm 16,26$ ppm. Konsentrasi antosianinnya sebesar 50,70 $\pm 2,31 \mathrm{ppm}$. Warna berdasarkan nilai ${ }^{\circ}$ Hue sebesar 85,02 \pm 1,57 (kuning kemerahan) dengan konsentrasi kuersetinnya sebesar 2612,40 $\pm 408,94$ ppm. Sedangkan hasil uji organoleptik adalah skor aroma 3,2 (kuat), skor kecerahan 4,2 (terang), dan skor warna 1,25 (merah pucat).

\section{KESIMPULAN}

Berdasarkan uji statistika metode Tukey, jenis perendaman dan varietas bawang merah berpengaruh nyata terhadap parameter kadar air, vitamin C, total fenolik, antosianin, aktivitas antioksidan, inhibisi radikal bebas, dan warna (chroma). Berdasarkan uji peringkat diperoleh perlakuan terbaik adalah tepung bawang merah dari varietas Bima dengan perlakuan perendaman asam askorbat 0,2 $\%$ selama 30 menit. Karakteristik dari tepung bawang ini memiliki kadar air 4,03 $\pm 0,79 \%$ (bb), kadar abu 4,45 $\pm 0,13$ $\%$ (bb), lemak 1,24 $\pm 0,64 \%$ (bb) protein 15,56 $\pm 0,28 \%$ (bb), vitamin C 61,94 $\pm 4,11 \mathrm{mg} / 100 \mathrm{~g}$, total fenol $256,39 \pm$ 16,26 ppm, antosianin 50,70 $\pm 2,31 \mathrm{ppm}$, kuersetin 2612,40 \pm 408,94 ppm, aktivitas antioksidan ekuivalen 225,72 \pm 4,07 $\mu \mathrm{g} / \mathrm{mL}$, inhibisi radikal bebas $83,05 \pm 1,69 \%$, nilai ${ }^{\circ}$ Hue 85,02 (kuning kemerahan) dan skor aroma 3,2 (kuat), skor kecerahan 4,2 (terang) dan skor warna 1,25 (merah pucat).
Penanganan pascapanen bawang merah varietas lokal (Bima dan Sembrani) menjadi tepung merupakan teknik tepat guna yang efektif dan efisien sebagai pangan fungsional yang baik untuk kesehatan dan tahan lama.

\section{UCAPAN TERIMA KASIH}

Ucapan terima kasih disampaikan kepada Deva Krisna Kadarani yang telah membantu analisis pada penelitian ini.

\section{DAFTAR PUSTAKA}

AOAC (Association of Official Analytical Chemist) (2005). Official Method of Analysis of the Association Analytical of Chemist. The Association of Official Analysis Chemist, Inc., Arlington.

BPS (Balai Pusat Statistik) (2012). Laporan Bulanan Sosial dan Ekonomi Edisi 40 September 2013. Katalog BPS:9199017.

Andarwulan, N., Batari, R., Sandrasari, D.A., Bolling, B. dan Wijaya, H. (2010). Flavonoid content and antioxidant activity of vegetables from Indonesia. Food Chemistry 121(4): 1231-1235.

Andarwulan, N., Kurniasih, D., Apriadi, R.A., Rahmat, H., Roto, A.V. dan Bolling, B.W. (2012). Polyphenols, carotenoids, and ascorbic acid in underutilized medicinal vegetables. Journal of Functional Food 4(1): 339-347.

Andarwulan, N. dan Faradilla, R.H.F. (2012). Pewarna Alami untuk Pangan. SEAFAST Center. Bogor.

Anwar, A. (2009). Natural Polysulfides Reactive Sulfur Spesies from Allium with Applications in Medicine and Agriculture. Thesis. Chemis, Pharmazie, Bio- und Werkstoffwissenschaffen. Universität des Saarlandes, Saarbrücken, Jerman.

Cheng, A., Chen, X., Jin, Q., Wang, W., Shi, J. dan Liu, Y (2013). Comparison of phenolic content and antioxidant capacity of red and yellow onions. Czech Journal of Food Sciences 31(5): 501-508.

Davidson, M.S., Sofos, J.N. dan Banen, A.L. (2005). Antimicrobials in Food Third Edition. Boca Raton (USA): CRC Press Taylor dan Francis Group. Hal.: 143-158.

Dong, Y., Wang, D., Li, M., Hu, X. dan Zhao, G (2010). One new pathway for allium discoloration. Food Chemistry 119(2): 548-553. 
Edwar, Z., Suyuthie, H., Yerizal, E. dan Sulatri, D. (2011). Pengaruh pemanasan terhadap kejenuhan asam lemak minyak goreng sawit dan minyak goreng jagung. Journal Indonesia Medical Associated 61(6): 248-252.

Farida (2008). Buku Penuntun Praktikum Kimia Pangan. IPB Press, Bogor.

Hongyan, L., Zeyuan, D., Honghui, Z., Charli, H., Ronghua, L. dan Christoper, J. (2012). Highly pigmented vegetables: anthocyanin compositions and their role in antioxidant activities. Food Research International 46(1): 250-259.

Ignat, I., Volf, I. dan Popa, V.I. (2011). A critical review of methods for characterisation of compounds in fruit and vegetables. Food Chemistry 126(4): 1821-1835.

Jaelani (2007). Khasiat Bawang Merah. Kanisius. Yogyakarta.

Jayathunge, K.G.L.R., Kapilarathne, R.A.N.S., Thilakarathne, B.M.K.S., Fernandol, M.D., Palipane, K.B. dan Prasanna, P.H.P. (2012). Develpoment of a methodology for production dehydrated tomato powder and study the acceptability of the product. Journal of Agricultural Technology 8(2): 765-773.

Linder, M.C. (2010). Biokimia Nutrisi dan Metabolisme. Aminudin P, penerjemah. Jakarta (ID): UI Press. Terjemahan dari: Nutritional Biochemistry and Metabolism.

Lu, X., Qadiri, A.H.M., Ross, C.F., Powerss, J.R., Tang, J.T. dan Rasco, B.A. (2011). Determination of total phenolic content and antioxidant capacity of onion (Allium cepa) and shallot (Allium oscaninii) using infrared spectroscopy. Food Chemistry 129(2): 637-644.

Marinova, D., Ribarova, F. dan Atanassova, M. (2005). Total phenolics and total flavonoids in Bulgarian fruits and vegetables. Journal of University of Chemical Technology and Metallurgy 40(3): 255-260.

Mogren, L.M., Olsson, M.E. dan Gertsson, U.E. (2006). Quercetin content in field cured onions (Allium cepa L.): Effects of cultivar, lifting time, and nitrogen fertilizer level. Journal of Agriculture and Food Chemistry 54: 6185-6191.

Mulia, S.A. (2008). Teknik pengeringan bawang merah dengan cara perlakuan suhu dan tekanan vakum. Buletin Teknik Pertanian 13(2): 79-82.

Nuutila, A.M., Puuponen, R., Aarni, M. dan OksmanCaldentey, K.M. (2003). Comparison of antioxidant activities of onion and garlic extracts by inhibition of lipid peroxidation and radical scavenging activity. Food Chemistry 81(4): 485-493.
Phani, C.R.S., Viaykumar, C., Umamaheswara, K. dan Sindhuja, G. (2010). Quantitative analysis of quercetin in natural sources by RP-HPLC. International Journal of Research in Pharmaceutical and Biomedical Sciences 1(1): 19-22.

Rajeswari, G., Susanna, S., Prabhansakar, P. dan Rao, V. (2013). Influence of onion powder and its hydrocolloid blends on pasta dough, pasting, microstructure, cooking and sensory characteristics. Food Bioscience 4: 13-20.

Rodrigo, N.C., Santos, D.T. dan Meireles, M.A.A. (2011). Non-thermal stabilization mechanism of anthocyanins in model and food systems-an overview. Food Research International 44(2): 499-509.

Rodrigues, A.S., Pérez-Gregorio, M.R., GarcíaFalcón, M.S., SimalGándara, J. dan Almeida, D.P.F. (2011). Effect of meteorological conditions on antioxidant flavonoids in Portuguese cultivars of white and red onion. Food Chemistry 124(1): 303-308.

Rosso, V dan Mercadante, A.Z. (2007). The high ascorbic acid content is the main cause of the low stability of anthocyanin extracts from acerola. Food Chemistry 103(3): 935-943

Sancho, L.E.G., Yahia, E.M. dan Aguilar G.A.G. (2011). Identification and quantification of phenols, carotenoid, and vitamin $\mathrm{C}$ from papaya (Carica papaya L. cv Maradol) fruit determined by HPLC-DAD-MS/MSESI. Food Research International 44(5): 1284-1291.

STAJ (Science and Technology Agency of Japan). (2002). Standard table of food compotition in Japan. Tokyo (JPN): Ministry of Finance Printing Bureau.

Setyadjit, Sukasih, E. dan Amiarsi, D. (2013). Teknologi Pengolahan Bawang Merah. Laporan Hasil Penelitian. BB Litbang Pascapanen Pertanian.

Soininen, T.H., Jukarainen, N., Julkunen-Tiitto R., Karjalainen, R. dan Vepslainen, J.J (2012). The combined use of constrained total line shape H NMR and LC MS/MS for quantitative analysis of bioactive components in yellow onion. Journal of Food Composition and Analysis 25(2): 208-214.

Takaya, Y., Kondo, Y., Furukawa, T. dan Niwa, M., (2003). Antioxidant constituents of Radish Sprout (Kaiwaredaikon), Raphanus sativus L. Journal of Agriculture and Food Chemistry 51: 8061-8066.

Vanini, L.S. dan Hirata, T.A. (2009). Extraction and stability of anthocyanins from the Benitake grape cultivar (Vitis vinifera L.). Brazilian Journal of Food Tcehnology 12(3): 213-219. 
Zang, J., Wang, D. dan Zhao, G. (2013). Mechanism of discoloration in processed garlic and onion. Trends in Food Science and Technology 30(2): 162-173.
Zussiva, A., Laurent, B.K. dan Budiyati, C.S. (2012). Ekstraksi dan analisis zat warna biru (antosianin) dari bunga telang (Clitoria ternatea) sebagai pewarna alami. Jurnal Teknologi Kimia dan Industri 1(1): 356-365. 